Max-Planck-Institut für demografische Forschung

Max Planck Institute for Demographic Research

Konrad-Zuse-Strasse 1 - D-18057 Rostock - GERMANY

$\mathrm{Tel}+49$ (0) 3812081 - 0; Fax +49 (0) 3812081 - 202;

http://www.demogr.mpg.de

MPIDR WORKING PAPER WP 2009-032

NOVEMBER 2009

\title{
Why Do Women in Former Communist \\ Countries Look Unhappy? \\ A Demographic Perspective
}

Junji Kageyama (kageyama@demogr.mpg.de)

This working paper has been approved for release by: James W. Vaupel (jwv@demogr.mpg.de), Head of the Laboratory of Survival and Longevity.

(C) Copyright is held by the authors.

Working papers of the Max Planck Institute for Demographic Research receive only limited review. Views or opinions expressed in working papers are attributable to the authors and do not necessarily reflect those of the Institute. 


\title{
Why Do Women in Former Communist Countries Look Unhappy?: A Demographic Perspective
}

\author{
Junji Kageyama* \\ Max Planck Institute for Demographic Research \\ Konrad-Zuse-Strasse 1, 18057 Rostock, Germany \\ and \\ Department of Economics, Meikai University \\ Akemi 1, Urayasu, Chiba 279-8550, Japan
}

March 25, 2009

\begin{abstract}
This paper investigates the causes of the positive correlation between happiness and the sex gap in happiness between women and men observed in Europe. Departing from a variety of hypotheses that are based on the sex differences at the individual level, this paper tests whether the positive correlation can be explained by the sex difference in life expectancy. The mechanisms working behind are as follows. First, national average happiness affects the sex gap in life expectancy negatively because men are more fragile to stress (unhappiness). Second, the sex difference in life expectancy influences the sex gap in happiness negatively because it affects the chance of being a widow for women. Using a 3SLS approach, it found that both effects are significant and that the direct effects between happiness and the happiness gap are insignificant. These results indicate that the positive correlation between happiness and the happiness gap is an artifact of the demographic compositional effect resulted from the sex gap in life expectancy.
\end{abstract}

Keywords: Happiness; Life Expectancy

\footnotetext{
*Tel: +49 3812081228, Fax: +49 3812081528, E-mail: kageyama@demogr.mpg.de
} 


\section{Introduction}

A number of disparities between former communist European countries and the other European countries, often referred to as an "East-West divide", have been reported in various disciplines. One of the most famous EastWest divide is the "mortality divide" (Bobak and Marmot, 1996). Life expectancies in Eastern European countries are found to be distinguishably lower than these of Western European countries.

There is also a divide in the sex difference in life expectancy. Men's low life expectancies in former communist countries result in large sex differences in life expectancies in these countries (see e.g. Watson, 1995; McKee and Shkolnikov, 2001).

Other instances of the East-West divides are found in happiness. For one thing, national average happiness, $H P$ is generally lower in former communist countries. This is not surprising considering the political disorder and economic turmoil triggered by the fall of communism. Anther example is the difference of the average happiness level between women and men, $H P G A P$. The sex differences are relatively smaller in former communist countries. The levels and the sex differences of happiness are presented in Table 1 for sample countries for which the data are available in the latest survey (European and World Values Surveys, wave 4). ${ }^{1}$

Place Table 1 around here

Figure 1 displays the correlation between $H P$ and $H P G A P$ for all sample periods (EWVS, waves 2-4). As speculated from the trend that both the levels and sex differences are lower in former communist countries, they are positively correlated. However, the mechanism that connects these two variable is not yet understood. One possible explanation would be that women's happiness is more elastic to social surroundings, indicating that women's happiness rises more than men's happiness in happier environments. This seems to be consistent with an idea that women generally express their emotion more freely. In fact, happiness data show that the ratio of respondents who choose the top category of happiness and the ratio of those who choose the bottom category are both higher for women.

It is also possible to hypothesize that the positive correlation relates to gender-specific social norms that pressure women to be feminine and men to be masculine. Strict gender-specific social norms may be negatively affecting the happiness levels of both women and men, but women's happiness more significantly.

Among a variety of hypotheses, this study examines whether the positive correlation can be attributed to a demographic compositional factor caused

\footnotetext{
${ }^{1}$ The details of data are described in Subsection 2.1 and in Appendix.
} 
by the sex gap in life expectancy between women and men, $L E G A P$. The mechanisms connecting $H P, H P G A P$, and $L E G A P$ are as follows. First, $H P$ affects $L E G A P$ negatively. This is because psychological stress (unhappiness) adversely affects survival and that the effect of psychological stress on mortality is more severe for men. ${ }^{2}$ Weidner and Cain (2003) for example contend that the substantial increase in coronary heart disease observed in Eastern Europe after the fall of communism which resulted in the region's dramatic health deterioration is principally caused by psychosocial stress and that this has a bigger impact on men because men cope less effectively with stress. Also, Möller-Leimkühler (2003) argues that traditional masculinity prevents men from seeking help and that this is the reason why men cope less effectively with psychological stress and adopt maladaptive strategies such as excessive alcohol consumption. These findings suggest that $H P$ adversely affects $L E G A P$, presuming psychological stress is reflected on $H P$.

Following this mechanism, LEGAP is expected to influence $H P G A P$ (and $H P$ as well) negatively. This is because an increase in $L E G A P$ affects the composition of marital status by increasing the women's widowhood ratio. A change in $L E G A P$ generates an impact at the socio-demographic level. Subsequently, as the happiness level is lower for the widowed, the compositional adjustment in marital status affects women's average happiness and $H P G A P$.

Each of these mechanisms is found to be significant in previous studies. Kageyama (2009) examined these relationships with an international crosscountry data set, and reported both that $H P$ negatively affects $L E G A P$ and that $L E G A P$ negatively influences $H P G A P$.

Putting these two mechanisms together, it is expected that $H P$ and $H P G A P$ are positively correlated even though there is no direct relationship. The relationship presented in Figure 1 may be explained by these two mechanisms.

To test this hypothesis, LEGAP, HPGAP, and $H P$ are simultaneously regressed on one another with 3SLS. If there exists a direct relationship between $H P$ and $H P G A P$, the effect of $H P$ on $H P G A P$ (or the reverse effect) would be significant. Alternatively, if the relationship is merely an artifact of the demographic compositional effect caused by $L E G A P, H P$ would be significant on explaining $L E G A P$ and $L E G A P$ would be significant on explaining $H P G A P$, while $H P$ and $H P G A P$ are insignificant on explaining each other.

The remainder of this article is organized as follows. The regression strategies and the results are respectively presented in Section 2 and Section

\footnotetext{
${ }^{2}$ This does not necessarily mean that the level of psychological stress is higher for men. On the contrary, women face a higher risk of depression. See e.g. Mirowsky and Ross (1995).
} 
3. The details of data, such as the definitions and data sources, are presented in Appendix. The main results are that the direct correlation between $H P$ and $H P G A P$ is spurious and that $L E G A P$ is working as the intermediary connecting the two variables. In addition, it is demonstrated that being a former communist country is insignificant on explaining both the smaller $H P G A P$ and the larger $L E G A P$ observed in the region while it adversely affects $H P$. It is also suggested that others' survival may be more important than one's own survival prospect on explaining $H P$. Section 5 concludes.

\section{Regression Strategies}

\subsection{Happiness Data}

Happiness data used in this study are taken from the European and World Values Surveys, wave 2 (1989-93), 3 (1994-99) and 4 (1999-2004). Wave 1 is excluded because no communist country was in the sample. Among various questions, respondents are asked about the feeling of happiness. Following the statement, "Taking all things together, would you say you are...," they are asked to choose one from "Very happy (4)", "Quite happy (3)", "Not very happy (2)", and "Not at all happy (1)."

As the data are subjective, there are concerns whether the data satisfy the basic objectiveness that are crucial for comparative studies. Common issues include whether questioners are not influencing respondents' answers or whether wording is neutral. In addition, when the data are used at aggregate level across cultures and periods, other issues arise, such as whether respondents can correspond to the entire population or whether the definition of happiness is the same across societies and periods.

Despite these issues, happiness data have been used in a number of studies in various disciplines, including sociology, psychology, economics, political science, and demography, and provided meaningful insights in these fields. Following these literatures, this study utilizes happiness data, but with caution.

To construct the variables for regression analyses, the national average of happiness, $H P$, and the difference in happiness level between women and men, HPGAP, are calculated for each country in each wave (countrywave). The number of respondents is, on average, 1,323 (708 women and 616 men) per country-wave that at least contains the data with regard to age, sex, marital status (which can be separated into the married, the separated or divorced, the widowed, and the never married), and happiness. The maximum is 4,072 (2,180 women and 1,892 men) in Spain (wave 2), and the minimum 568 (272 women and 296 men) in Finland (wave 2). The number of countries included in each wave are respectively, 23 (wave 2), 19 (wave 3 ), and 27 (wave 4 ). 


\section{$2.2 \quad$ Data Set}

The data set is the three-period panel with 69 observations (34 countries). For cross-country panels, a common method of estimation is to apply the fixed-effect model with country dummies. In this way, country dummies capture the unobservable country-specific effects. However, the present panel data set is heavily unbalanced. This implies that applying the fixed-effect model with country dummies is not realistic. Therefore, the data set is treated as a pooled data set. The details of data, such as the definitions and data sources, are presented in Appendix.

\subsection{Regression Equations}

To test whether the correlation between $H P$ and $H P G A P$ is explained by $L E G A P$, the following three equations are regressed simultaneously by 3SLS, treating $L E G A P, H P$, and $H P G A P$ as endogenous.

RE (1): $L E G A P$ on $H P, L E, L Y P C, L R, S M G A P$, and $F C D$

RE (2): HPGAP on $H P, L E G A P, U E G A P$, and $F C D$

RE (3): $H P$ on $H P G A P, L E G A P, L E, L Y P C, F T$, and FCD

$\mathrm{RE}$ (1) examines the significance of $H P$ on explaining $L E G A P$. Since lower $H P$ raises men's mortality more than women's mortality, $H P$ is expected to affect $L E G A P$ negatively. The equation also includes the level of life expectancy for both sexes, $L E$, the log of purchasing-power-parity adjusted per-capita GDP, $L Y P C$, women's labor force ratio, $L R$, the sex difference in smoking rate between women and men, $S M G A P$, as exogenous variables, since they are found to be significant in Kageyama (2009). The expected effects are negative for $L E$ and $S M G A P$, and positive for $L Y P C$ and $L R$. In addition, former-communist-country dummy, $F C D$, is incorporated to test whether being a former communist country has a significant effect on explaining the large life expectancy gap in former communist countries.

$\mathrm{RE}$ (2) investigates the significance of $H P$ and $L E G A P$ on explaining $H P G A P$. If $L E G A P$ is significant and $H P$ is insignificant on explaining $H P G A P$, the relationship between $H P$ and $H P G A P$ would be merely an artifact of $L E G A P$. Alternatively, if both effects are found to be significant, the positive correlation between $H P$ and $H P G A P$ would be the mixed outcome of both effects. Finally, if $H P$ is significant and $L E G A P$ is insignificant, demographic factors related to $L E G A P$ can not explain the positive correlation.

The equation also includes the sex difference in unemployment rate between women and men, $U E G A P$, and $F C D$ as exogenous variables. $U E G A P$ is expected to affect $H P G A P$ negatively since being unemployed affects happiness negatively. As for $F C D$, the coefficient would be signifi- 
cantly negative if it explains the lower happiness gap in former communist countries.

$\mathrm{RE}(3)$ is included to test the significance of $H P G A P$ on explaining $H P .^{3}$ If $H P G A P$ is significant on explaining $H P$, it suggests the existence of direct relationship between $H P$ and $H P G A P$. Otherwise, the relationship is considered to be spurious. Other variables included in the equation are $L E G A P, L E, L Y P C, F T$, and $F C D$. The level of unemployment itself is found to be insignificant and omitted. The expected effects are positive for $L E, L Y P C$, and $F T$, and negative for $L E G A P$ and $F C D$.

\section{$3 \quad$ Regression Results}

\subsection{General Results}

Table 2 presents the regression results. Equations (1) include all variables as well as period dummies, and equations (2) and (3) include only significant variables and are respectively regressed with 3SLS and 2SLS. Period dummies are insignificant in all three equations (the smallest $p$-value $=0.21$ ), and thus, omitted. Applying 2SLS instead of 3SLS does not change the results significantly.

The results in RE (1) are consistent with previous studies such as Kageyama (2009). The coefficients of $L E$ and $S M G A P$ are significantly negative, and the coefficients of $L Y P C$ and $L R$ are significantly positive. As for $H P$, the coefficient becomes significantly negative, in particular, at the $1 \%$ level when insignificant variables are omitted. $F C D$, on the other hand, is found to be insignificant.

In $\mathrm{RE}(2)$, the results are also consistent with our expectations. Both $L E G A P$ and $U E G A P$ become significant with the expected signs while $H P$ and $F C D$ are insignificant.

Finally, in RE (3), LEGAP, $L Y P C$ are found to be significant with the expected signs while $H P G A P$ and $L E$ are insignificant. As for $F T$ and $F C D$, they are not significant at the $10 \%$ level in equation (1), but they become significant respectively at the $1 \%$ and $10 \%$ levels in equation (2).

\subsection{Relationship between Happiness and Happiness Gap}

With regard to the direct relationship between $H P$ and $H P G A P$, the results indicate that the correlation is spurious. Equations (1) and (4) in RE (2) and equations (1) and (6) in RE (3) respectively show that $H P$ is insignificant on explaining $H P G A P$ and vice versa. As demonstrated in equations (5)

\footnotetext{
${ }^{3}$ The aim of regressing $H P$ is to test the significance of $H P G A P$. As $H P$ is inter-related with various variables, such as income, inequality, fertility, education, and institutional environments, and these relationships are complex, explaining the cross-country variation in $H P$ would require its own study.
} 
in $\mathrm{RE}(2)$ and (7) in $\mathrm{RE} \mathrm{(3),} \mathrm{they} \mathrm{are} \mathrm{significant} \mathrm{only} \mathrm{when} L E G A P$ is omitted. They lose significance with the inclusion of $L E G A P$.

Instead, the correlation between $H P$ and $H P G A P$ can be explained by $L E G A P$. In RE (1), the coefficient of $H P$ is significantly negative on explaining $L E G A P$. This supports the hypothesis that psychological stress (unhappiness) adversely affects survival and that the effect of psychological stress on mortality is more severe for men. Subsequently, in RE (2), the coefficient of $L E G A P$ becomes significantly negative on explaining HPGAP. This supports the existence of the marital-status compositional effect. These results indicate that $L E G A P$ is working as the intermediary to connect $H P$ and $H P G A P$. Namely, $L E G A P$ becomes smaller in happier countries and smaller $L E G A P$ contributes to smaller HPGAP.

\subsection{East-West Divide}

The analysis can be extended to test the existence of an East-West divide. In RE (3), equations (2) and (12) suggest the existence of the negative effect of $F C D$ on $H P$. As in equation (2), the inclusion of $L E G A P$ reduces the level of significance and makes the coefficient closer to zero, but it is still significant at the $10 \%$ level. Although FCD becomes insignificant at the $10 \%$ level when 2SLS is applied, the results here suggest that being a former communist country negatively affects happiness as 3SLS yields more efficient estimates.

On the other hand, in $\mathrm{RE}$ (1), $F C D$ is found to be insignificant on explaining $L E G A P$. Although $F C D$ is significant in equation (9) when $H P$ is omitted, it loses the explanatory power with the inclusion of $H P$ as shown in equation (8). Therefore, the large $L E G A P$ in former communist countries can be attributed to the lower $H P$ in these countries. Being a former communist country per se is not the cause of the large life expectancy gap. This is consistent with the findings in previous studies such as Weidner and Cain (2003) that one of the most crucial factors that attribute to the large life expectancy gap in Eastern Europe is psychological stress.

Finally, in RE (2), $F C D$ is also found to be insignificant on explaining $H P G A P$. FCD is significant in equation (11) when $L E G A P$ is omitted, but it becomes insignificant with the inclusion of $L E G A P$ as shown in equation (10). Therefore, the differences in $H P G A P$ between countries can be attributed directly to $L E G A P$ and indirectly to $H P$ while being a former communist country per se does not have any effects on $H P G A P$.

\subsection{My life or Others' Lives?}

Equation (14) in RE (3) shows that the coefficient of $L E$ is significantly positive on explaining $H P$ when $L E G A P$ is omitted. This is intuitive. Although the directions of the causality may be mutual, $H P$ and $L E$ being 
positively correlated is not a surprising result. However, the inclusion of $L E G A P$ changes this result. As shown in equation (13), the coefficient of $L E$ becomes negative with the inclusion of $L E G A P$ although the significance level is lower.

The relationship between $L E$ and $H P$ needs to be investigated further before concluding that $L E$ indeed affects $H P$ negatively. ${ }^{4}$ There may be a mechanism that yield a negative relationship between $L E$ and $H P$, or the explanatory power may be discarded as insignificant. Alternatively, the relationship may be indeed positive, and the negative correlation may be simply an artifact.

Although analyzing this relationship is beyond the scope of this paper, the result here presents the possibility that the positive effect of $L E$ on $H P$ (or life satisfaction) found in previous studies (e.g. Ovaska and Takashima, 2006; Deaton, 2008) could be inflated. $H P$ may be more closely related to $L E G A P$ than $L E$ and the omission of $L E G A P$ can possibly result in the strong positive correlation between $L E$ and $H P$, reflecting the negative relationship between $L E$ and $L E G A P$. Higher $L E$ leads to smaller $L E G A P$, and smaller $L E G A P$ results in higher $H P$.

This result is interesting because it suggests that, not only our own survival, but also the survival of others affects our happiness. Although it is often implicitly assumed in theoretical models that utility, or happiness, solely depends on one's own situation, not others' situation, the result here indicates that others' situation could possibly be more significant on explaining one's utility, or happiness. ${ }^{5}$ As demonstrated in Bernheim and Stark (1988), one's utility also depends on others' utility and this interdependency may have a significant impact on one's utility.

\section{Concluding Remarks}

This paper examines happiness in a demographic perspective. As presented in Figure 1, the correlation between happiness and the sex gap in happiness does not show any sign of demographic effects on the surface. However, there is a strong demographic effect underneath caused by the sex gap in life expectancy and the composition of marital status. The results indicate that the correlation between happiness and the sex gap is merely an artifact of the demographic effect.

The results also suggest that happiness data need to be treated carefully, especially, at aggregate level. For example, taking the national average

\footnotetext{
${ }^{4}$ Bjørnskov (2008) reported that happiness had a negative effect on life expectancy using a 2SLS approach. This may be related with the negative correlation between $L E$ and $H P$ found in the present study.

${ }^{5}$ It is also possible to say that it is due to a sample bias. Although we can ask the feeling of happiness to those who have experienced the death of one's spouse, we cannot ask the same question to those who have experienced the death of one's own.
} 
of happiness without removing compositional effects and using it for any sorts of analyses may yield misleading results. The national average does not necessarily represent the happiness level of a typical individual of the corresponding country.

Last but not least, the question given by the title "Why Do Women in Former Communist Countries Look Unhappy?" needs to be answered. Comparing women in former communist countries and those in other European countries, the results suggest that women in former communist countries are less happier because of political disorder and economic turmoil following the fall of communism. Being a former communist country is still significant on explaining the national average happiness although the effect is much smaller after controlling for the sex gap in life expectancy.

On the other hand, comparing them with men in the same country, the results demonstrate that the source of their unhappiness is the sex gap in life expectancy. The chance of being a widow is higher in former communist countries due to the large sex gap in life expectancy, and this adversely affects women's average happiness. This is maybe why some people, like one of my colleagues, get an impression that women, in particular, old women, look unhappy in former communist countries. The chance of encountering widows is higher in these countries.

\section{A Data Appendix}

\section{A.1 Definitions of variables}

$H P$ : National average happiness (EWVS, 2008)

HPGAP: The difference of the sex-specific average happiness between women and men (EWVS, 2008)

$L E$ : Life expectancy for both sexes (UN, 2008)

$L E G A P$ : The difference of life expectancy between women and men (UN, 2008)

LY PC: GDP per capita (purchasing-power-parity adjusted) (Penn World Table 6.2, 2008)

FT: Fertility rate (births per woman) (World Bank, 2008)

$L R$ : Women's labor force ratio (World Bank, 2008)

$U E G A P$ : The difference in unemployment rate between women and men (World Bank, 2008)

$S M G A P$ : The difference of smoking rate between women and men (WHO Europe, 2007) 


\section{A.2 Data sources}

- Heston, A, Summers, R., and Aten, B., (2006). Penn World Table Version 6.2. Center for International Comparisons of Production, Income and Prices at the University of Pennsylvania.

- European and World Values Surveys, (2006). European and World Values Surveys four-wave integrated data file, 1981-2004, v.20060423. Surveys designed and executed by the European Values Study Group and World Values Survey Association. File Producers: ASEP/JDS, Madrid, Spain and Tilburg University, Tilburg, the Netherlands. File Distributors: ASEP/JDS and GESIS, Cologne, Germany.

- United Nations Population Division, (2007). World Population Prospects: The 2006 Revision (http://data.un.org/).

- WHO Regional Office for Europe, (2007). Health for All database (HFA-DB), Copenhagen (http://www.euro.who.int/hfadb).

- World Bank, (2008). World Development Indicators 2008 (CD-ROM), Washington, D.C.

\section{A.3 Sample periods}

The sample periods consist of three periods, 1990-1994 (2), 1995-1999 (3), and 2000-2004 (4). This follows the sample periods of the dependent variable, LEGAP. Happiness data are attached to these periods according to wave number indicated in the parentheses. As for the variables from PWT, WHO Europe, and World Bank, the averages are taken for each variables within each period.

\section{References}

Bernheim, B. Douglas and Oded Stark, "Altruism Within the Family Reconsidered: Do Nice Guys Finish Last?," 1988, 78, 1034-1045.

Bjørnskov, Christian, "Healthy and Happy in Europe? On the Association between Happiness and Life Expectancy Over Time," Social Science E Medicine, 2008, 66, 1750-1759.

Bobak, Martin and Michael Marmot, "East-West Mortality Divide and its Potential Explanations: Proposed Research Agenda," British Medical Journal, 1996, 312, 421-425.

Deaton, Angus, "Income, Health, and Well-Being Around the World: Evidence from the Gallup World Poll," Journal of Economic Perspectives, 2008, 22, 53-72. 
Kageyama, Junji, "Happiness and sex difference in life expectancy," MPIDR Working Paper, 2009, 2009-009.

McKee, Martin and Vladimir Shkolnikov, "Understanding the toll of premature death among men in eastern Europe," British Medical Journal, 2001, 323, 1051-1055.

Mirowsky, John and Catherine E. Ross, "Sex Differences in Distress: Real or Artifact?," American Sociological Review, 1995, 60, 449-468.

Möller-Leimkühler, Anne Maria, "The Gender Gap in Suicide and Premature Death or: why are men so Vulnerable?," European Archives of Psychiatry and Clinical Neuroscience, 2003, 253, 1-8.

Ovaska, Tomi and Ryo Takashima, "Economic Policy and the Level of Self-Perceived Well-Being: An International Comparison," Journal of Socio-Economics, 2006, 35, 308-325.

Watson, Peggy, "Explaining rising mortality among men in Eastern Europe," Social Science \&3 Medicine, 1995, 41, 923-934.

Weidner, Gerdi and Virginia S. Cain, "The Gender Gap in Heart Disease: Lessons From Eastern Europe," American Journal of Public Health, 2003, 93, 768-770. 


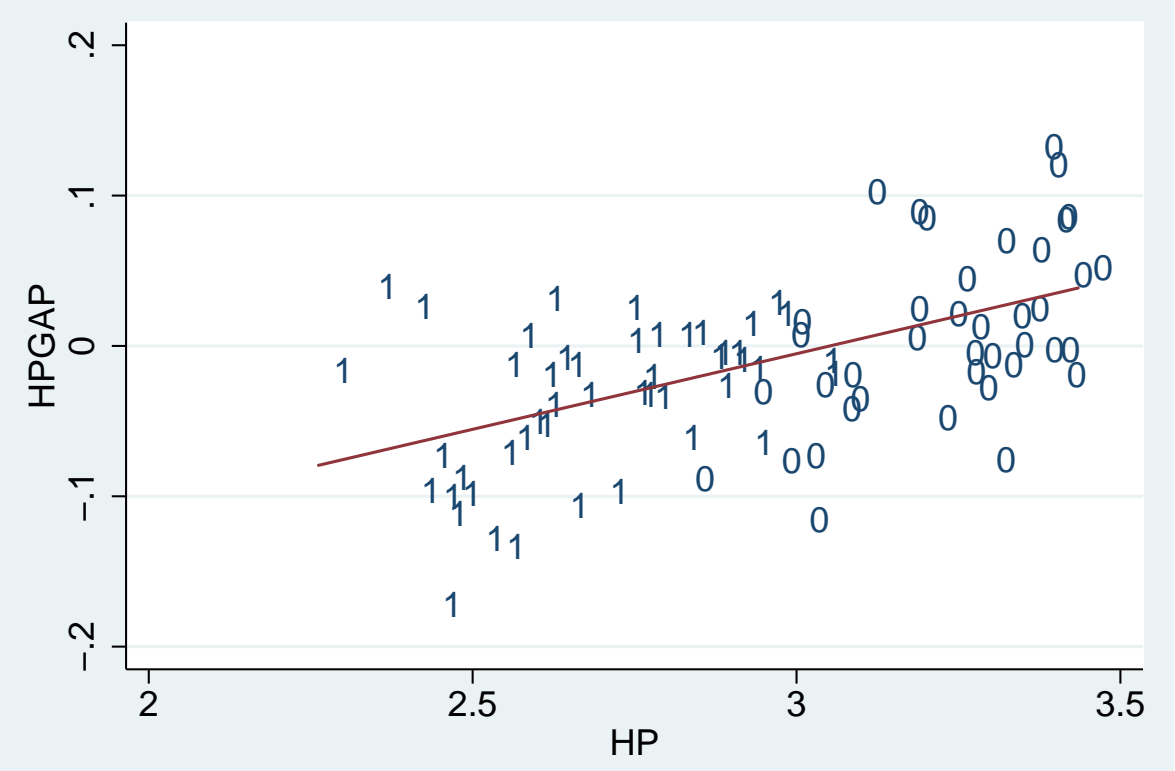

1: Former Communist Country, 0: Otherwise

Figure 1: Correlation between Happiness and Happiness Gap 
Table 1: Happiness and Happiness Gap (National Averages)

\begin{tabular}{|c|c|c|c|c|c|}
\hline Country & $F C D$ & $H P$ & Country & $F C D$ & HPGAP \\
\hline Romania & 1 & 2.39 & Russian & 1 & -0.172 \\
\hline Russian & 1 & 2.43 & Portugal & 0 & -0.115 \\
\hline Ukraine & 1 & 2.43 & Bulgaria & 1 & -0.111 \\
\hline Bulgaria & 1 & 2.44 & Ukraine & 1 & -0.100 \\
\hline Republic of Moldova & 1 & 2.53 & Belarus & 1 & -0.097 \\
\hline Albania & 1 & 2.59 & Italy & 0 & -0.076 \\
\hline Latvia & 1 & 2.61 & Luxembourg & 0 & -0.075 \\
\hline Belarus & 1 & 2.69 & Slovenia & 1 & -0.064 \\
\hline Estonia & 1 & 2.71 & Spain & 0 & -0.035 \\
\hline Slovakia & 1 & 2.74 & Greece & 0 & -0.030 \\
\hline Lithuania & 1 & 2.79 & Austria & 0 & -0.027 \\
\hline Hungary & 1 & 2.84 & Slovakia & 1 & -0.020 \\
\hline Poland & 1 & 2.85 & Denmark & 0 & -0.019 \\
\hline Macedonia & 1 & 2.89 & Bosnia and Herzegovina & 1 & -0.018 \\
\hline Greece & 0 & 2.91 & France & 0 & -0.017 \\
\hline Slovenia & 1 & 2.91 & Republic of Moldova & 1 & -0.012 \\
\hline Croatia & 1 & 2.93 & Latvia & 1 & -0.007 \\
\hline Czech republic & 1 & 2.95 & Hungary & 1 & -0.007 \\
\hline Italy & 0 & 2.95 & Poland & 1 & -0.004 \\
\hline Germany & 0 & 2.97 & Finland & 0 & 0.006 \\
\hline Portugal & 0 & 3.00 & Lithuania & 1 & 0.008 \\
\hline Bosnia and Herzegovina & 1 & 3.02 & Macedonia & 1 & 0.015 \\
\hline Spain & 0 & 3.06 & Germany & 0 & 0.016 \\
\hline Finland & 0 & 3.15 & Belgium & 0 & 0.020 \\
\hline Malta & 0 & 3.15 & Czech repblic & 1 & 0.022 \\
\hline France & 0 & 3.24 & Malta & 0 & 0.025 \\
\hline Austria & 0 & 3.26 & Estonia & 1 & 0.025 \\
\hline Luxembourg & 0 & 3.28 & Romania & 1 & 0.026 \\
\hline Sweden & 0 & 3.29 & Croatia & 1 & 0.029 \\
\hline Belgium & 0 & 3.31 & Albania & 1 & 0.031 \\
\hline Ireland & 0 & 3.38 & Netherlands & 0 & 0.048 \\
\hline Denmark & 0 & 3.39 & Iceland & 0 & 0.052 \\
\hline Netherlands & 0 & 3.40 & Sweden & 0 & 0.070 \\
\hline Iceland & 0 & 3.43 & Ireland & 0 & 0.084 \\
\hline Average & 1 & 2.71 & Average & 1 & -0.025 \\
\hline Average & 0 & 3.20 & Average & 0 & -0.005 \\
\hline
\end{tabular}

The country is former communist if $F C D=1$, and otherwise if $F C D=0$. 
Table 2: Regression Results (Endogenous Variables: LEGAP, HPGAP, HP)

\begin{tabular}{|c|c|c|c|c|c|c|c|c|c|c|c|c|c|c|c|c|c|c|c|c|}
\hline \multirow{2}{*}{\multicolumn{2}{|c|}{$\begin{array}{l}\text { Endogenous varaible } \\
\text { Explanatory Variables }\end{array}$}} & \multicolumn{7}{|c|}{ RE (1): LEGAP } & \multicolumn{5}{|c|}{ RE (2): $H P G A P$} & \multicolumn{7}{|c|}{ RE (3): $H P$} \\
\hline & & $H P$ & $L E$ & $\angle Y P C$ & $L R$ & SMGAP & $F C D$ & R-sq & $H P$ & LEGAP & UEGAP & $F C D$ & $\mathrm{R}$-sq & HPGAP & LEGAP & $L E$ & $\angle Y P C$ & $F T$ & $F C D$ & $\mathrm{R}$-sq \\
\hline (1) & 3SLS & $\begin{array}{l}-5.682 \\
-2.28 * *\end{array}$ & $\begin{array}{l}-0.268 \\
-3.70 * * *\end{array}$ & $\begin{array}{r}2.829 \\
6.23\end{array} * * *$ & $\begin{array}{c}0.056 \\
1.90 *\end{array}$ & $\begin{array}{l}-0.051 \\
-2.11 * *\end{array}$ & $\begin{array}{r}0.274 \\
0.37\end{array}$ & 0.79 & $\begin{array}{r}0.018 \\
0.28\end{array}$ & $\begin{array}{l}-0.019 \\
-3.64 * * *\end{array}$ & $\begin{array}{l}-0.0064 \\
-3.90 * * *\end{array}$ & $\begin{array}{r}0.016 \\
0.58\end{array}$ & 0.33 & $\begin{array}{r}0.222 \\
0.37\end{array}$ & $\begin{array}{l}-0.068 \\
-3.32 * * *\end{array}$ & $\begin{array}{r}-0.015 \\
-1.27\end{array}$ & $\begin{array}{l}0.303 \\
5.66 * * *\end{array}$ & $\begin{array}{r}0.111 \\
1.44\end{array}$ & $\begin{array}{r}-0.078 \\
-1.22\end{array}$ & 0.84 \\
\hline (2) & 3SLS & $\begin{array}{l}-6.310 \\
-4.25 * * *\end{array}$ & $\begin{array}{l}-0.236 \\
-4.94 * * *\end{array}$ & $\begin{array}{r}2.799 \\
6.522^{* * * *}\end{array}$ & $\begin{array}{l}0.059 \\
2.47 * *\end{array}$ & $\begin{array}{l}-0.055 \\
-3.41 * * *\end{array}$ & & 0.76 & & $\begin{array}{l}-0.019 \\
-7.14 * * *\end{array}$ & $\begin{array}{r}-0.0066 \\
-4.30 * * *\end{array}$ & & 0.31 & & $\begin{array}{l}-0.051 \\
-5.07 * * *\end{array}$ & & $\begin{array}{l}0.254 \\
7.03 * * *\end{array}$ & $\begin{array}{l}0.126 \\
2.71\end{array}$ *** & $\begin{array}{l}-0.088 \\
-1.87\end{array}$ & 0.84 \\
\hline (3) & 2SLS & $\begin{array}{l}-5.277 \\
-2.75 * * *\end{array}$ & $\begin{array}{l}-0.258 \\
-3.15 * * *\end{array}$ & $\begin{array}{r}2.451 \\
4.43 * * *\end{array}$ & $\begin{array}{l}0.097 \\
2.25 * *\end{array}$ & $\begin{array}{r}-0.052 \\
0.02 * *\end{array}$ & & 0.80 & & $\begin{array}{r}-0.019 \\
-6.73 * * *\end{array}$ & $\begin{array}{l}-0.0063 \\
-3.46 * * *\end{array}$ & & 0.32 & & $\begin{array}{r}-0.049 \\
-4.51 * * *\end{array}$ & & $\begin{array}{c}0.259 \\
5.75 * * *\end{array}$ & $\begin{array}{l}0.164 \\
2.65 * * *\end{array}$ & $\begin{array}{r}-0.074 \\
-1.19\end{array}$ & 0.85 \\
\hline (4) & 3SLS & $\begin{array}{l}-6.392 \\
-4.31 * * *\end{array}$ & $\begin{array}{l}-0.232 \\
-4.71 * * *\end{array}$ & $\begin{array}{r}2.748 \\
6.12 \text { *** }\end{array}$ & $\begin{array}{l}0.057 \\
2.37 * *\end{array}$ & $\begin{array}{l}-0.053 \\
-3.25 * * *\end{array}$ & & 0.76 & $\begin{array}{r}-0.015 \\
-0.39\end{array}$ & $\begin{array}{l}-0.021 \\
-3.99 * * *\end{array}$ & -0.0067 & & 0.27 & & $\begin{array}{l}-0.052 \\
-5.04 * * *\end{array}$ & & $\begin{array}{l}0.251 \\
6.77 * * *\end{array}$ & $\begin{array}{l}0.124 \\
2.66\end{array} * * *$ & $\begin{array}{l}-0.086 \\
-1.82\end{array}$ & 0.84 \\
\hline (5) & $3 S L S$ & $\begin{array}{l}-5.653 \\
-3.14 * * *\end{array}$ & $\begin{array}{l}-0.233 \\
-4.30 * * *\end{array}$ & $\begin{array}{c}2.705 \\
5.25 * * *\end{array}$ & $\begin{array}{l}0.073 \\
2.74 * *\end{array}$ & $\begin{array}{l}-0.068 \\
* \quad 0.02\end{array} * * *$ & & 0.78 & $\begin{array}{r}0.119 \\
6.25 * * *\end{array}$ & & $\begin{array}{l}-0.0048 \\
-2.95 * * *\end{array}$ & & 0.39 & & $\begin{array}{l}-0.050 \\
-4.75 * * *\end{array}$ & & $\begin{array}{l}0.241 \\
6.25 * * *\end{array}$ & $\begin{array}{r}0.137 \\
2.81\end{array}$ *** & $\begin{array}{l}-0.102 \\
-2.05 * *\end{array}$ & 0.85 \\
\hline (6) & 3SLS & $\begin{array}{l}-6.333 \\
-4.27 * * *\end{array}$ & $\begin{array}{l}-0.237 \\
-4.91 * * *\end{array}$ & $\begin{array}{r}2.804 \\
6.53\end{array}$ *** & $\begin{array}{l}0.068 \\
2.42 * *\end{array}$ & $\begin{array}{l}-0.053 \\
-3.31\end{array}$ *** & & 0.76 & & $\begin{array}{l}-0.019 * * * \\
-7.10\end{array}$ & $\begin{array}{c}-0.0067 * * * \\
-4.35\end{array}$ & & 0.31 & $\begin{array}{r}0.436 \\
0.71\end{array}$ & $\begin{array}{l}-0.044 \\
-3.20 \text { *** }\end{array}$ & & $\begin{array}{l}0.250 \\
6.88 \text { **** }\end{array}$ & $\begin{array}{l}0.107 \\
1.87\end{array}$ ** & $\begin{array}{l}-0.095 \\
-1.97 * *\end{array}$ & 0.86 \\
\hline (7) & $3 S L S$ & $\begin{array}{l}-5.512 \\
-3.75 * * *\end{array}$ & $\begin{array}{c}-0.285 \\
-5.24\end{array}$ & $\begin{array}{c}2.853 \\
6.62 * * *\end{array}$ & $\begin{array}{l}0.078 \\
2.94 * *\end{array}$ & $\begin{array}{c}-0.060 \\
* *-3.81\end{array} * * *$ & & 0.79 & & $\begin{array}{c}-0.019 \\
-7.26 * * *\end{array}$ & $\begin{array}{l}-0.0048 \\
-3.64 * * *\end{array}$ & & 0.30 & $\begin{array}{l}2.026 \\
3.77 * *\end{array}$ & & & $\begin{array}{l}0.240 \\
6.12 \text { *** }\end{array}$ & $\begin{array}{l}0.125 \\
1.95 *\end{array}$ & $\begin{array}{l}-0.153 \\
-3.36 * * *\end{array}$ & 0.83 \\
\hline (8) & $3 \mathrm{SLS}$ & $\begin{array}{l}-5.637 \\
-2.40 * *\end{array}$ & $\begin{array}{l}-0.247 \\
-5.05\end{array}$ *** & $\begin{array}{r}2.754 \\
6.61\end{array}$ & $\begin{array}{c}0.061 \\
2.49\end{array}$ & $\begin{array}{c}-0.058 \\
-2.66\end{array}$ *** & $\begin{array}{r}0.202 \\
0.31\end{array}$ & 0.78 & & $\begin{array}{r}-0.019 \\
-7.12 * * *\end{array}$ & $\begin{array}{l}-0.0067 \\
-4.32\end{array} * * *$ & & 0.31 & & $\begin{array}{l}-0.051 \\
-5.07 * * *\end{array}$ & & $\begin{array}{l}0.260 \\
6.5 * * *\end{array}$ & $\begin{array}{l}0.136 \\
2.47\end{array}$ ** & $\begin{array}{r}-0.078 \\
-1.39\end{array}$ & 0.84 \\
\hline (9) & 3SLS & & $\begin{array}{l}-0.319 \\
-5.87 * * *\end{array}$ & $\begin{array}{c}2.111 \\
6.64 * * *\end{array}$ & $\begin{array}{c}0.066 \\
2.19 * *\end{array}$ & $\begin{array}{l}-0.098 \\
-7.83\end{array} * * *$ & $\begin{array}{l}1.382 \\
3.63 \text { *** }\end{array}$ & 0.85 & & $\begin{array}{c}-0.019 \\
-7.23 * * *\end{array}$ & $\begin{array}{r}-0.0069 \\
-4.37 * * *\end{array}$ & & 0.30 & & $\begin{array}{l}-0.049 \\
-4.93 * * *\end{array}$ & & $\begin{array}{c}0.264 \\
6.58 \text { *** }\end{array}$ & $\begin{array}{l}0.161 \\
2.96\end{array} * * *$ & $\begin{array}{r}-0.074 \\
-1.33\end{array}$ & 0.85 \\
\hline (10) & 3SLS & $\begin{array}{l}-6.496 \\
-4.23 * * *\end{array}$ & $\begin{array}{l}-0.232 \\
-4.71\end{array} * * *$ & $\begin{array}{l}2.780 \\
6.48^{* * *}\end{array}$ & $\begin{array}{c}0.057 \\
2.38 \text { ** }\end{array}$ & $\begin{array}{r}-0.051 \\
-2.99\end{array} * * *$ & & 0.76 & & $\begin{array}{l}-0.020 \\
-5.27 * * *\end{array}$ & $\begin{array}{r}-0.0065 \\
-4.20\end{array} * * *$ & $\begin{array}{r}0.007 \\
0.68\end{array}$ & 0.30 & & $\begin{array}{l}-0.052 \\
-5.02 * * *\end{array}$ & & $\begin{array}{l}0.252 \\
6.91 * * *\end{array}$ & $\begin{array}{r}0.122 \\
2.59\end{array}$ *** & $\begin{array}{c}-0.085 \\
-1.79\end{array}$ & 0.84 \\
\hline (11) & 3SLS & $\begin{array}{l}-5.564 \\
-3.16 * * *\end{array}$ & $\begin{array}{l}-0.243 \\
-4.47\end{array} * * *$ & $\begin{array}{c}2.813 \\
5.62\end{array}$ **** & $\begin{array}{c}0.081 \\
3.02 * *\end{array}$ & $\begin{array}{l}-0.076 \\
* * * 05 * *\end{array}$ & & 0.78 & & & $\begin{array}{l}-0.0052 \\
-2.84 * * *\end{array}$ & $\begin{array}{l}-0.054 \\
-4.43 * * *\end{array}$ & 0.24 & & $\begin{array}{r}-0.039 \\
-3.89\end{array} * * *$ & & $\begin{array}{l}0.250 \\
6.64 * * *\end{array}$ & $\begin{array}{l}0.133 \\
2.76\end{array}$ *** & $\begin{array}{l}-0.123 \\
-2.49\end{array} * *$ & 0.85 \\
\hline (12) & 3SLS & $\begin{array}{l}-4.942 \\
-3.37 * * *\end{array}$ & $\begin{array}{l}-0.336 \\
-5.78\end{array} * * *$ & $\begin{array}{c}2.965 \\
6.86 * * *\end{array}$ & $\begin{array}{l}0.078 \\
2.54 * *\end{array}$ & $\begin{array}{l}-0.070 \\
-4.23\end{array} * * *$ & & 0.79 & & $\begin{array}{l}-0.018 \\
-6.74 * * *\end{array}$ & $\begin{array}{r}-0.0071 \\
-4.50 * * *\end{array}$ & & 0.32 & & & & $\begin{array}{l}0.263 \\
5.80\end{array}$ & $\begin{array}{l}0.250 \\
4.37\end{array} * * *$ & $\begin{array}{l}-0.209 \\
-3.87\end{array} * * *$ & 0.82 \\
\hline (13) & 3SLS & $\begin{array}{l}-6.014 \\
-4.03 * * *\end{array}$ & $\begin{array}{l}-0.309 \\
-4.88\end{array} * * *$ & $\begin{array}{c}2.869 \\
6.66 * * *\end{array}$ & $\begin{array}{c}0.042 \\
1.75 *\end{array}$ & $\begin{array}{l}-0.043 \\
-2.50 \text { ** }\end{array}$ & & 0.77 & & $\begin{array}{l}-0.019 \\
-7.16 * * *\end{array}$ & $\begin{array}{l}-0.0068 \\
-4.47\end{array} * * *$ & & 0.31 & & $\begin{array}{l}-0.079 \\
-4.39 * * *\end{array}$ & $\begin{array}{c}-0.021 \\
-1.87 *\end{array}$ & $\begin{array}{l}0.316 \\
6.38 \text { *** }\end{array}$ & $\begin{array}{l}0.096 \\
2.07\end{array}$ ** & $\begin{array}{c}-0.080 \\
-1.74 *\end{array}$ & 0.81 \\
\hline (14) & $3 S L S$ & $\begin{array}{l}-5.792 \\
-3.88 * * *\end{array}$ & $\begin{array}{l}-0.25 \\
-4.01\end{array}$ & $\begin{array}{r}2.844 \\
6.56 * * *\end{array}$ & $\begin{array}{l}0.080 \\
2.65 * *\end{array}$ & $\begin{array}{l}-0.066 \\
-4.07\end{array} * * *$ & & 0.78 & & $\begin{array}{r}-0.019 \\
-6.99 * * *\end{array}$ & $\begin{array}{r}-0.0069 \\
-4.42 * * *\end{array}$ & & 0.31 & & & $\begin{array}{r}0.023 \\
3.44 * * *\end{array}$ & $\begin{array}{c}0.197 \\
4.33^{\text {**** }}\end{array}$ & $\begin{array}{l}0.225 \\
4.29\end{array} * * *$ & $\begin{array}{l}-0.130 \\
-2.40\end{array} * *$ & 0.84 \\
\hline
\end{tabular}

The top figures are the estimated coefficients, the bottom ones are t-statistics.

$* * *, * *$, and $*$ respectively indicate the significance level at $\mathrm{p}<0.01, \mathrm{p}<0.05$, and $\mathrm{p}<0.10$.

The number of observations: 69 .

Equations (1) include period dummies. 